\title{
GENDER ISSUES IN APPLICATION OF ISLAMIC LAW IN NIGERIA
}

\section{Muhammad S. Umar}

Fellow Wissenschaftskolleg zu Berlin; Director of Institute for Study of Islamic Thought in Africa Program of African Studies Northwestern University Evanston, IL. U.S.A.

\section{Abstract}

This essay explores gender issues in the contemporary application of Islamic law in the Muslim majority-states of northern Nigeria. Brief political background helps to explain the shari'a codes enacted by the legislatures of the states, drawing largely from the classical formulations of Maliki school of Islamic law. Women were among the first to be prosecuted and sentenced to death by stoning for the offence of zinā. To provide effective legal defense for the accused women, their lawyers and activists for women buman rights had to argue in Islamic law before they could convince Shari'a Courts of Appeal to overturn the sentences of death by stoning and set the women free. In the process, women activists learned a lot about the classical formulations of Maliki school of Islamic law, where they discovered the rich flexibility of Islamic thought, and that has empowered them to articulate Islamic criticisms against gender bias in the recently enacted shari' a codes.

Keywords: Gender Issues, Application of Islamic Law, Maliki School of Thought, Nigeria

\section{A. Introduction}

Fatima Mernissi opens the introduction to her famous book, The Veil and the Male Elite, with a brief account of an episode at her local 
grocery store that encapsulates the problem I address in this essay. She recounts how her simple question "Can a woman be a leader of Muslims?" shocked her grocer, and led one customer to invoke God's protection against "the catastrophes of the times." She adds that a schoolteacher, the third person in the grocery store at the time, "stood slowly caressing his wet mint leaves, and then hit me with the badith that he knew would be fatal: Those who entrust their affairs to a woman will never know prosperity!' Silence fell on the scene. There was nothing I could say." Mernissi describes her reaction thus:

I discretely left the grocery store without another word. What could I have said to counterbalance the force of that political aphorism, which is as implacable as it is popular? Silenced, defeated, and furious, I suddenly felt the urgent need to inform myself about this hadith, and to search out the texts where it is mentioned, to understand better its extraordinary power over the ordinary citizens of a modern state. ${ }^{2}$

The most striking points in this remarkable episode include the violence that Mernissi suffered when she was bit with a hadith that proved "fatal," "implacable," "popular," and having "force" and "extraordinary power" not only to silence her, but also to defeat and humiliate her. Mernissi's encounter is a clear pointer to wider intellectual problems of contemporary Muslims who are debating crucial issues confronting "ordinary citizens of a modern state." After she felt silenced, Mernissi recovered her voice through an intellectual odyssey into the classics of Islamic intellectual traditions, where she found the discursive resources that empowered her to demonstrate that the particular hadith she was hit with is in fact a weak hadith that, according to the classical Islamic jurisprudence, can only serve as a conjectural but not categorical source for deriving rules of Islamic law that every Muslim must obey. For Mernissi, "a study of the religious texts that everybody knows but no one really probes," opens the pathway for her to acquire the discursive resources she needed to strike back against the negative consequences of manipulating sacred texts that constitute "a structural

1 Fatima Mernissi, The Veil and the Male Elite: A Feminist Interpretation of Women's Rights in Islam," translated by Mary Jo Lakeland, (Reading, Massachusetts: AddisonWesley Publishing Co, 1991), p. 1.

2 Ibid, p. 2. 
Gender Issues in Application of Islamic Law in Nigeria

characteristic of the practice of power in Muslim societies." As Muslim men found warrant from Islamic intellectual traditions to exclude women from leadership, Muslim women can also find counter-warrant in the same traditions for their inclusion in leadership.

A Nigerian illustration of Mernissi's predicament shows remarkable similarities. In analyzing the various reactions to the recent developments in shari'a application in Nigeria, Ayesha Imam observes that: "The dominant discourse was that to criticize_-even in the mildest ways - the sharia'anization project was to be by definition anti-sharia, anti-North [predominantly Muslim region of Nigeria], and anti-Islam." Criticism of any aspects attracts accusations of apostasy, raising the specter of death penalty. Ayesha Imam observes that in the "context of vigilantes and the failure of the state authorities to maintain security and the rule of law, these accusations are very real threat, [and they] raise the likelihood of physical attack, if not actual death." vigilante violence has forced some Muslim critics of the shar" 'a project to recant their earlier skepticisms, and many more to resort to selfcensorship. A report by Human Rights Watch observes that recent expansion of Islamic law in the northern states of Nigeria has created a climate unconducive to freedom of expression, leading to "a form of self-censorship among critics-including academics, human rights activists, members of women's organizations, lawyers and otherswho were willing to express strong reservations about shari' $a$ in private conversations but not in public." 5 This self-censorship is "based primarily on a fear of being labeled as anti-Islamic - a charge commonly labeled against perceived critics of shari"a." Human Rights Watch reports further that "the consequences of this self-censorship have

3 Ibid, pp. 8-9.

4 Ayesha Imam, "Fighting the Political (Ab)Use of Religion in Nigeria: BOABAB for Women's Human Rights, Allies and Others," in Warning Signs of Fundamentalisms, edited by A. Imam, J. Morgan \& N. Yuval-Davis, published by Women Living under Muslim Law, 2004) http://www.wluml.org/english/pubsfulltxt.shtml? cmd $\% 5 B 87 \% 5 \mathrm{D}=\mathrm{i}-87-98541$. p. 128. Accessed on May 24, 2007.

${ }^{5}$ Human Rights Watch, (September 2004), "Political Sharia"? Human Rights and Islamic Law in Northern Nigeria," Human Rights Watch, volume 16, no 9(A), pp. 86-90. 
been a virtual silence on the part of the northern civil society about the more controversial aspects of $\operatorname{shari}^{\prime} a, \ldots$ and, for a long time, the absence of genuine, open public debate on these questions." "This unhealthy intellectual development reveals a remarkable similarity to Mernissi's encounter with the problematic of gender in contemporary Islamic discourses in Morocco. As in Mernissi's case, Muslim women in Nigeria have resorted to invoking the classics of Islamic law in order to combat gender bias and discrimination in the contemporary application of Islamic law-a point analyzed in more details below.

Of course Mernissi's predicament is quite common in the contemporary Islamic discourses taking place in diverse contexts. Charles Kurzman observes that a central preoccupation in the discourses of Islamic modernists since the middle of the nineteenthcentury has been the imperative to defend the right to speak on topical issues of the day from the perspective of Islamic modernism, the Islamic legitimacy of which has often been contested. ${ }^{7}$ The discursive strategy of emphasizing the inadequacy of traditional categories of Islamic thought, and urging new ways of rethinking Islam in the modern world - reiterated by recent thinkers such as Abdullah an-Na'im ${ }^{8}$ and Muhammad Arkoun' — are yet to dislodge deeply engrained patterns of traditional Islamic thought that are sometimes the explicit issues in contention or the subtext within the debates. An alternative strategy of recovering selected elements within Islamic classics has so far marshaled strong arguments that demonstrate the Qur'anic bases for an Islamic theology of liberation, the Islamic roots of democracy, social pluralism, peace-building, human rights, as well as Islamic warrants for gender equality. ${ }^{10}$ This strategy of excavating Islamic classics for

${ }^{6}$ Ibid, p. 88.

7 Charles Kurzman, ed., Modernist Islam 1840-1940,, (New York: Oxford University Press, 2002), pp. 6-20.

8 Abdullah A An-Na'im. Toward an Islamic Reformation, (Syracuse, NY: Syracuse University Press, 1990).

9 Mohammed Arkoun, Rethinking Islam, trans. and ed. by Robert D. Lee, (Boulder, CO: Westview Press, 1994); and Mohammed Arkoun, The Unthought in Contemporary Islamic Thought (London: Saqi, 2002).

${ }^{10}$ For example, see: Farid Esack Farid, Qur'an, Liberation and Pluralism, (Rockford, MA: Oneworld Publications, 1997); Khaled Abou El Fadl, Speaking in God's Name, 
Gender Issues in Application of Islamic Law in Nigeria

warrants to support different positions within the contemporary debates among Muslims is worthy of further development: it should be expanded and fortified with equally Islamically authentic rebuttals against the potentially violent responses with death fatwas and takfir.

\section{B. Political Context of Nigeria}

International media coverage of application of Islamic law in contemporary Nigeria rarely pays adequate attention to the complexities of the country, most notably its multi-ethnic and multi-religious composition, and the long grip of the military on power. Also relevant are two decades (1980s-1990s) of implementing World Banks and IMF structural adjustment programs, whose net outcome has increased poverty and disillusionment, leaving majority of Nigerians with no option but seeking solace in primordial identities of ethnicity and religion. Therefore when the country was preparing return to civilian rule, politicians found it easier to instrumentalize ethnicity or religion to mobilize constituencies to vote them into power, without offering meaningful policies and programs that could salvage the ravages of both prolonged military rule and structural adjustment programs.

In May of 1999, Chief Olusegun Obasanjo was sworn-in as the elected president of Nigeria after nearly two decades of military rule dominated by generals, namely: 1) Muhammadu Buhari (r. 1983-1985); 2) Ibrahim Babangida (r. 1985-1993);1 3) Sani Abacha (r.1993 to

(Oxford, England: Oneworld Publications, 2001); A.S. Moussalli, Islamic Quest for Democracy, Pluralism, and Human Rights, (Gainesville, FL: U.P. of Florida, 2001); A. Sachedina, The Islamic Roots of Democratic Pluralism, (New York: Oxford University Press, 2001); Abdolkarim Soroush, Reason, Freedom, and Democracy in Islam: Essential writings of Abdolkarim Soroush, translated, edited, and with a critical introduction by Mahmoud Sadri, Ahmad Sadri, (New York, N.Y.: Oxford University Press, 2000); M. Shahrur, Dirasat al-Islamiyya al-Mu'asira fi al-Dawla wa al-Mujtama', (Damascus: Al-Ahli, 1994); Amina Wadud, Qur'an and Woman, New York: Oxford University Press, 1999.

${ }^{11}$ During Babangida's reign Chief M.K.O. Abiola, a Yoruba Muslim from the south-west region together with Alhaji Baba Gana Kingibe a Kanuri Muslim from the north-east region, were the presumed winners of the annulled elections held on June 12, 1993. Although the elections were thought to be free and fair, Abiola never became president, and when he declared himself president of Nigeria in 1994, he was arrested and detained by General Sani Abacha until both of them died in 1998. 
Muhammad S. Umar

1998); ${ }^{12}$ and 4) Abdusalami Abubukar (r. 1998-1999), who organized the elections that brought Chief Obasanjo to power. These four generals were all Muslims who hailed from the northern part of Nigeria, an important issue in the national political discourse during the lead-up to the 1999 election. Vigorous arguments were articulated to support the contention that power-shift_from the predominantly Muslim northern region of the country to the predominantly Christian southern region - was necessary for national reconciliation after the devastation of the two decades of military rule, and also for breaking the Muslim/ Northern monopoly on power.

Jibrin Ibrahim observes that political mobilization on ethnoregional basis is not new in Nigerian politics. He dates the first phase of its evolution to 1958-1965 when the politics of nationalism and decolonization was "characterized by the mobilization of ethnoregional identities with the objective of gaining access to regional power, where significant real power still lay." 13 This phase ended with the Nigerian civil war c. 1966-1970 that tragically exposed the serious hazards of ethno-regionalism. The second phase that Jibrin locates in the civil war period saw efforts "directed toward mobilizing the nation to fight the civil war and resolve the national crisis"14 that crippled Nigeria's first republic $c .1950-1966$. In the third and final phase, the politics of ethno-regionalism was transformed by the rise of "a unitary state and consequent weakening of the regional bases of power." Ibrahim captures the serious consequences in this insightful remark:

The sole issue informing political mobilization then became the conquest of federal power at the center. This tendency has been exacerbated over the past decade, the years of structural adjustment, due to enhanced centralization, concentration, and reduction [original italics] of the resources available even at the center. This means that groups are obliged to block others' access or to displace those who already have access if

\footnotetext{
${ }^{12}$ Between August and November 1993, Chief Shonenkan, a Yoruba Christian from the south-west, was President of Nigeria and head of interim national government that was overthrown by General Sani Abacha.

${ }^{13}$ Jibrin Ibrahim, "Political Transition, Ethnoregionalism, and the 'Power Shift' Debate in Nigeria," Issue: A Journal of Opinion, vol. 27:1 (1999), p. 13.

${ }^{14}$ Ibid.
} 
Gender Issues in Application of Islamic Law in Nigeria

they are to eat from the national cake. Politics has become a zero-sum game. The discursive categories defining the game are ethnoregional. ${ }^{15}$

This observation shows that political and economic issues are the drivers of the politics of power-shift, while ethnoregionalism is basically an instrument of accessing dwindling economic resources centrally controlled by concentrated political power of the federal government of Nigeria. It is therefore important to maintain a balanced perspective on the relative significance of ethno-regional forces-along with their religious aspects-while focusing analysis on the political and economic drivers of Nigerian politics. ${ }^{16}$ One can even argue that although the divisive agents of religious and ethno-regional mobilization have frequently used the rhetoric of threatening secession from the federation of Nigeria, they have failed to cause the actual break-up of country despite two concrete attempts, namely: the civil war of 19661970 and Major Okar's abortive coup of $1990 .{ }^{17}$ The economic integration of Nigeria has become strong enough to absolve not only the tensions from religious and ethno-regional mobilization, but also the serious strains of zero-sum politics. Though under-appreciated, coalition, alliance, and compromise have been significant features of Nigerian politics that made soft-landing possible out of the volatile situation of the last years of the military grip on power, especially under General Sani Abacha.

The strengths of politics of coalition, alliance and compromise are discernible in the power-shift politics under which Chief Obasanjo emerged as the consensus candidate acceptable to major political constituencies for various reasons. The Northern/Muslim power elite saw Obasanjo as an elder statesman who had the distinguished honor of being the first and only Nigerian military leader who willingly handed power to democratically elected President of Nigeria in the person of Alhaji Shehu Shagari (r. 1979-1983), a prominent member of the

\footnotetext{
${ }^{15}$ Ibid.

${ }^{16}$ L. Diamond, A. Kirk-Greene, and O. Oyediran, eds. Transition without End: Nigerian Politics and Civil Society under Babangida, (Boulder, CO Lynne Rienner Publishers, 1997).

${ }^{17}$ For example, see: "The Making, [and] Crushing of a Coup: A Blow-by-Blow Account of Nigeria's Bloodiest, But Botched Coup," African Concord, 7 May 1990.
} 
Muhammad S. Umar

northern power elite. As a born-again Christian, Chief Obasanjo was also a pleasant choice for Nigerian Christians who thought Muslims had dominated power for too long. The military could not have had ideological or institutional opposition to a decorated four-star general and former leader of Nigeria to assume the same post again. The international community also welcomed Chief Obasanjo who used to enjoy moral authority on account of being the only military ruler who willingly handed power back to civilians. ${ }^{18}$ Additionally, Chief Obasanjo seems to regard himself as a messiah of Nigeria, declaring that his election was a "mandate from God to transform Nigeria." 19 Eight years later at the end of his two terms in office, and having woefully failed to amend the constitution so he can have a third term, Chief Obasanjo seemed to have lost the overwhelming goodwill and confidence he had when he took over in May of 1999_a very interesting issue that cannot be discussed in more details here.

\section{Application of Islamic Law in Nigeria}

Almost immediately after Nigeria's return to "democratic rule" in 1999, serious problems suddenly appeared in the public sphere, and carried in screaming headlines by news-media around the world. Violent conflicts linked to ethnic and religious problems frequently manifested in Muslim-Christian riots, claiming the lives of thousands of innocent citizens while also traumatizing many more through loss of beloved relatives, friends, business associates, properties, and other valuable possessions. ${ }^{20}$ The religious and ethnic violent conflicts should be

${ }^{18}$ M. Camdessus, "Supporting Nigeria’s recovery: An IMF’s perspective." Monday, Abuja, Nigeria, March 22, 1999.

${ }^{19}$ General Olusegun Obasanjo, "Nigeria Will Rise Again: The text of the Address by General Olusegun Obasanjo, following his election as president of the Federal Republic of Nigeria." Wednesday March 3, 1999.

${ }^{20}$ For example, see the reflections of BBC correspondent in Nigeria, Bernaby Phillips, "Farewell to Nigeria," BBC News Online, Sunday, 8 July, 2001, 17:58 GMT 18:58 UK. http://news.bbc.co.uk/2/hi/programmes/from our own correspondent/ 1429159.stm, Accessed on May 26, 2007; Dan Isaacs, "Islam in Nigeria: Simmering Tensions,” BBC NEWS: http://news.bbc.co.uk/go/pr/fr/-/2/hi/africa/3155279.stm, Published: 2003/09/24 11:01:13 GMT (C BBC MMVI) Accessed March 17, 2006; Also, Bala Usman, "Violent Ethnic Conflicts in Nigeria: Beyond Myths and Mystifications," Analysis, vol. 2 No 2, February 2003. 
Gender Issues in Application of Islamic Law in Nigeria

understood within the travails of Nigeria as a modern nation-state with multi-ethnic and multi-religious citizenry, the various aspects of which have been analyzed by several scholars. ${ }^{21}$

Also grabbing the attention of the international community are the judgments of Islamic courts condemning women to death by stoning as legislated in recent enlargement of the scope of Islamic law in Nigeria. Within the federal structure of Nigeria, states have constitutional mandate to enact laws on many local issues, including criminal law. The elected governor of Zamfara State, Alhaji Ahmed Sani, signed a law passed by the State Legislative House of Assembly in 2000, thereby expanding the jurisdiction of Zamfara State Sharia Courts to include deciding criminal cases according to Islamic law. ${ }^{22}$ Governor Sani's actions in this regard should be seen within the context of identity politics. Ayesha Imam argues that since Zamfara State has "little infrastructure, few natural resources, relatively few people with high formal education.... Governor Sani has to find some way to make himself popular. He did it by claiming to undertake sharianization."23 Soon afterward, an upsurge of popular support for application of Islamic

${ }^{21}$ For example, see: Eghosa E Osaghae, Crippled Giant: Nigeria Since Independence (Bloomington: Indiana University Press, 1998); Crawford Young, "The Impossible Necessity of Nigeria: A Struggle for Nationhood" Foreign Affairs, November/December 1996, http://www.foreignaffairs.org/1996/6.html, and A. Jega ed., Identity Transformation and Identity Politics under Structural Adjustment in Nigeria (Uppsala: Nordic Africa Institute, May 2000). Daniel J. Smith, A Culture of Corruption: Everyday Deception and Popular Discontent in Nigeria, (Princeton, NJ: Princeton University Press, 2006).

${ }^{22}$ For detailed and comparative analysis of the issues involved, see: Ruud Peters, The Reintroduction of Islamic Criminal Law in Northern Nigeria, A Study Conducted on Behalf of the European Commission, (Lagos, 2001); Philip Ostien, Jamila M. Nasir, Franz Kogelman, Comparative Perspectives on Shari'ah in Nigeria, (Ibadan: Spectrum Books, 2005). Ogbu U. Kalu, "Safiyya and Adamah: Punishing Adultery with Sharia Stones in the Twenty-First Century Nigeria," African Affairs, (2003), 102, pp. 389-408; Ibrahim A. Aliyu, "Shari'a Implementation So Far: Problems and Prospects," Journal of Islamic and Comparative Law, vol. 23 (2002), pp. 31-44; Center for the Study of Islam and Democracy (CAIS), The Implementation of Shari'a in a Democracy: The Nigerian Experience, (Washington, DC 2006), and Vincent O. Nmehielle, "Sharia Law in the Northern States of Nigeria: To Implement or Not to Implement, the Constitutionality is the Question," Human Rights Quarterly, volume 24 (2004), pp. 730-759.

${ }^{23}$ Ayesha Imam, "Fighting the Political (Ab)Use of Religion in Nigeria," p. 125. 
law left all the elected governors of states with Muslim majorities with no option but to demonstrate their serious commitment to applying Islamic law in their states. Many of the governors were not willing initially but when they began to be publicly accosted by angry mobs questioning their Islamic faith, the strength of popular expectation on the issue became unmistakable, especially for politicians who face reelection within couple of years. ${ }^{24}$ Political maneuvering around the popular demands for shari' a application became like riding the tiger by the tail. Even for the governors whose commitments were not in doubt, there was still the pressure to demonstrate that they meant business.

Shari'a has of course being part of Nigeria's legal system for centuries. ${ }^{25}$ Even after the imposition of British colonialism in 1903, application of shari'a continued alongside with British common and colonial laws. ${ }^{26}$ Penal Code and Criminal Procedure Code were enacted by the Northern Region of Nigeria at independence from British colonialism in 1960. While incorporating rules of Islamic law, these codes omitted many aspects of the classical formulations of fiqh, most notably the hudüd punishments of death by stoning and amputation of limps. Following the restructuring of Nigeria after the civil war of 1966-1970, the Northern Region of Nigeria ceased to exist as one geo-political entity and was replaced by the present-day nineteen states existing in the same geographic area. These states inherited the old shari' $a$ codes; twelve with Muslim majority populations are the states that have expanded the jurisdiction of the shari' $a$ to include the budüd punishments - one of the main aspects of all the changes introduced since 1999. Although wide differences exist among the twelve states, the older Penal Code and Criminal Procedure Codes have been replaced by the new ones with budüd provisions. A second set of legislations has

${ }^{24}$ Sanusi L. Sanusi "Fundamentalist Groups and the Nigerian Legal System: Some Reflections," in Warning Signs of Fundamentalism, p.79-82.

${ }^{25}$ Tijjani M. Naniya, "History of the Sharia in Some States of Northern Nigeria to circa 2000," Journal of Islamic Studies, volume 13, (2002), no 1, pp. 14-31.

${ }^{26}$ Muhammad S. Umar, Islam and Colonialism: Intellectual Responses of Muslims of Northern Nigeria to British Colonialism, (Leiden: Brill, 2006), pp. 40-55. Also see: Tijjani, M. Naniya, "Transformation of the Administration of Justice in Kano Emirates, 1903-1966,” Ph.D. Dissertation, Bayero University, Kano, Nigeria, 1990). 
Gender Issues in Application of Islamic Law in Nigeria

been enacted to reorganize judicial administration, grant shari' $a$ courts autonomy from their present integration into the magistrate courts that apply common law and Nigerian public law, establish a different hierarchy of shari' $a$ courts, and expand the appellate jurisdiction of Shari' $a$ Courts of Appeal. Finally, a third set of legislations has been passed into law to establish various statutory bodies, such Council of Ulama, Hisba Commission, Sharia Research Commission, etc. ${ }^{27}$ It is very important to note that wide differences exist in the legislations passed by the each of the 12 sharia-implementing states, ${ }^{28}$ even though all the details could not be fully analyzed here. It is equally important to note that shari' $a$ in Nigeria today includes not only these modern legislative enactments, but also the medieval formulations of Maliki fiqh, from which these shari'a codes were drawn, and which is also invoked in deciding cases in the shari'a courts.

\section{Gender, Women NGOs, and Application of Shari'a}

Among the early cases decided by shari' $a$ courts on the basis of

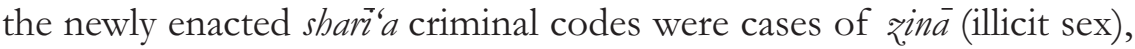
amputation for theft that was carried out in 2001 and one sentence of 80 lashings for zina by an unmarried woman, but reduced to 40 lashes when the sentence was executed-both cases were in Zamfara State. Similarly two judgments of lashing for zina by unmarried person and one for consumption of alcohol were carried out in Malumfashi town of Katsina State..$^{29}$ Death sentence (by stoning) has been imposed on two women: Safiya Husaini in Sokoto State and Amina Lawal in Katsina State. Both judgments were, however, overturned by Shari' $a$ Courts of Appeal in the two states. The success of the appeal was partly the result of campaigns by activist constituencies of human rights, women's rights, democracy promotion, local and international non-governmental

\footnotetext{
${ }^{27}$ Peters, Reintroduction of Islamic Criminal Law, pp. $13 \mathrm{ff}$.

${ }^{28}$ Phillip Ostien, "Islamic Criminal Law: What it means in Zamfara and Niger States," Journal of Public and Private Law, vol. 4 (2000), no 4, pp. 1-35.

${ }^{29}$ Peters, Reintroduction of Islamic Criminal Law, p. 14. For more details on other cases in shari'a court, see: Baobab, Sharia in Nigeria: The Journey So Far, http:// www.baobabwomen.org/publications womenshr.htm, (2003). Accessed on May 26, 2007, pp.10-20.
} 
organizations, the European Union, embassies of Western countries in Nigeria, and local and international media commentators. As developments in Nigeria unfolded, these different sets of actors mobilized personnel, discourses, and resources that made the difference in the final disposition of the two cases.

Since Muslim women are the majority of those prosecuted according to the new Islamic codes, non-governmental organizations for women's rights have had no option but to study Islamic law in order to mount effective defense of the poor Muslim women who found themselves in court facing charges of illicit sex. Safiyya Husaini and Amina Lawal are poor and uneducated rural women who could not make the kind of intellectual odyssey that Mernissi did; instead, they were rescued by non-governmental organizations for women's human rights. $B A O B A B$ For Women's Human Rights is one of the most prominent non-governmental organizations that spearheaded the defense in court of the two accused women. A defense team comprising several lawyers, Islamic scholars, and women's rights activists were able to overturn the conviction condemning the two women to death, on account of their successful legal strategy of marshalling arguments from classical manuals of Islamic law, and from Nigeria's law and constitution-see below for analysis of the legal arguments that won the appeal.

Following the Mernissi strategy of searching the Islamic intellectual heritage for empowering discourses to address gender inequality and injustice was not too difficult for BAOBAB, given its origins from "an ad hoc group of activists, social scientists, lawyers, and specialists in Muslim laws and Arabic who were responsible for executing the Women and Laws Nigeria Project, under the auspices of the International Solidarity Network of Women Living Under Muslim Laws [WLUML] from 1993 to 1996." At the end of the project the research team mopped into an NGO that adopts the mission of promoting “women's human rights principally via improving knowledge, exercise and development of rights under religious laws, customary laws and statutory laws." ${ }^{30}$ For over a decade now, Baobab's activism has included wide-ranging interventions in Muslim public discourses

${ }^{30}$ http://www.baobabwomen.org/history.htm Accessed on April 30, 2007. 
Gender Issues in Application of Islamic Law in Nigeria

in Nigeria via publications on ways of promoting Muslim women's human rights within Islamic law, raising public awareness and advocacy in the public policy arena as well as taking the legal defense of Muslim women prosecuted for illicit sex under the newly enacted shari'a penal codes. In all these cases, $\mathrm{BAOBAB}$ has shown a remarkable ability to mine the rich intellectual heritage of Islam for ideas to support more effective advocacy for Muslim women's human rights, as clearly demonstrated in Women's Rights in Muslim Laws: A Resource Document, published by Baobab in 2005.

The authors hope to counteract the troubling prevalence of Mernissi's predicament in Nigeria where "the mere mention of the word shari' a seems to render all policies and legislation above scrutiny or criticism, whatever their content." ${ }^{31}$ Against the widespread perception that shari' $a$ is the law directly given by God, the authors set themselves to demonstrate that "whilst religious laws may be based on divine revelations, they are necessarily also man-made, historical and social products, and therefore changeable." ${ }^{32}$ They achieve this goal by highlighting the several ways humans construct the enforceable rules of the shari'a. Most notably, the version of Islamic law applied in Nigeria is the Maliki interpretation, which takes its name from its founding figure, Imam Malik b. Anas; the same is true for three other Sunni interpretations also named after their founders, i.e. Hanafi, Shafi'i and Hanbali. Each of these four accepted interpretations of Islamic law "has variations according to the cultural, political, and socioeconomic contexts in which they were developed and the philosophy of reasoning that was accepted." None of these interpretations of Islamic law existed at the time of Qur'an revelation during the life time of the Prophet, and given the undeniable roles of the individual jurists in formulating these interpretations, it follows logically that "the laws they outline are clearly not direct divine revelations from God. Instead, they are laws developed through human judicial reasoning

${ }^{31}$ Ayesha M. Imam, Mufuliat Fijabi, and Hurera Akilu-Atta, Women's Rights in Muslim Laws: A Resources Document, (Lagos: Baobab for Women's Human Rights, 2005), p. 14.

${ }^{32}$ Ibid. p. 14.

Al-Jämíah, Vol. 45, No. 1, 2007 M/1428 H 
(ijtiha ad, in Arabic)." ${ }^{33}$ For our authors, demonstrating clearly the active roles of men (often excluding women) in formulating and interpreting rules of Islamic law is very important for enabling critical discussions of the recent legislative enactments of shari'a penal law in Nigeria, and also for challenging the notion that any criticisms of the contemporary fundamentalist interpretations of Islamic law is tantamount to questioning God's law-thereby giving advanced rebuttals to the anticipated quick resort to death fatwas.

For the Baobab authors, it is equally important to call attention to the diversity and variations of juristic opinions within shari'a that are very well recognized in the classical manuals of Islamic law, including the ones invoked in both the legislative enactments and the judicial rulings in Nigeria. Highlighting this salient point enables the authors to challenge effectively the claims that there is only one true version of absolutely correct Muslim laws that should never be examined critically; moreover this point also advocates implicitly the validity of making different choices within the diversity of the variously accepted interpretations of the shari'a. One obvious choice should focus on possibilities of protecting women's rights within the classical manuals of Islamic law, even though they bear the significant patriarchal influences of their historical origins. Making this point sufficiently clear is a good critique against the secularist activists who regard Islamic law as part of the problem for women's rights, and the Islamophobia often hiding behind calls to liberate Muslim women from their allegedly oppressive religion. The Baobab document shows that improved religious literacy can be effective response to the hegemonic politics of religious revival, which seems to demand subordination of women as a necessary tenet of Islam.

The main contentions summarized above are illustrated with reference to Qur'an 4:3, which states: "And if ye fear that ye will not deal fairly by the orphans, marry of the women, who seem good to you, two or three or four; and if ye fear that ye cannot do justice (to so many) then one (only) or (the captives) that your right hands possess. Thus it is more likely that ye will not do injustice." The authors remark

${ }^{33}$ Ibid, pp. 18-19. 
Gender Issues in Application of Islamic Law in Nigeria

that the first important point to note is that the verse says polygamy is allowed but not required; equally important are the specific conditions of fairness and equal treatment required before marrying more than one wife at a time. Next, the authors observe that the circumstances within which the verse was revealed were in the aftermath of the Battle of Uhud when many Muslim men lost their lives, leaving their womenfolk without providers in the Arabian tribal society where "few women and children had independent access to resources and therefore needed to have a claim for maintenance on a man through kinship or marriage." This short reference to asbäb al-nu₹ūl is interesting but not well developed; it is one of the few doctrines alluding to branches of Islamic thought apart from the main focus on figh.

Pursuing their analysis of the verse on polygamy, authors observe that different Muslim scholars have argued that the stringent conditions stipulated are impossible to meet; hence the verse effectively outlaws polygamy. Yet others have argued that even if the verse is not so interpreted, monogamy is certainly the model preferred. The authors highlight various laws and policies on polygamy in different Muslim countries, ranging from prohibition in Tunisia to the expectation prevalent in Nigeria that Muslims should practice polygamous marriage in order to follow the exemplary practice of Prophet Muhammad. Inbetween the two extremes are diverse laws allowing polygamy but only under court supervision (Malaysia), when each wife is provided with a separate residence (Sudan), or permitted but not encouraged or expected (India). By documenting these interpretations of Quran 4:3 and juxtaposing the different laws, policies and practices on polygamy, the point becomes undeniable: "What is assumed to be Muslim in one community may be unknown, or even be considered un-Islamic, in other Muslim communities." ${ }^{34}$

These critical engagements with the classical doctrines of Islamic law reveal the centrality of human interpretation in constructing the rules of Islamic law in many different ways, including significantly limiting or even prohibiting what the text of the Qur'an says is allowed. Once empowered by knowledge of diversity and variety within Islamic

${ }^{34}$ Ibid., 11-13. 
law, Baobab activists can now mount forceful rebuttals against the intimidating charges of apostasy, silencing dissent, and squelching alternative views by selective resort to Islamic classics, takfir and death fatwas-as earlier noted. ${ }^{35}$ Having thus solved the problem of inadequate knowledge of Islam that made many Muslims not confident enough to criticize politicized application of Islamic law in contemporary Nigeria, Baobab can now hope to draw more activists to promotion and defense of women's human rights through active participation in policy advocacy, coalition-building, and public enlightenment campaigns, where Baobab can deploy its newly acquired intellectual capital against its adversaries, most notably religious fundamentalists.

For example, in November 2006, BAOBAB held a national conference to commemorate its tenth anniversary. The conference's theme was "The Challenges of Religious Fundamentalisms and Globalization to Women's Human Rights," and was attended by participants from media, human rights organizations, philanthropic organizations, embassies and government agencies. ${ }^{36}$ The conference communiqué states that among the objectives of the conference was to analyze the "emerging trends of religious fundamentalism" and "widening the debate on women's rights and religion by bringing in perspectives that reflect the situation of women under the major religions in Nigeria." The participants commented on several issues relating to Islamic law, notably: "That much as it has suffered obvious distortions and misinterpretations, Islamic family law is replete with provisions that enhance, rather than disempower women in the pursuit of rights." The participants also observe that "there is a wide range of difference between what the law stipulates or requires, what the operators of the law are saying, what the learned are interpreting, and what the followers practice." These insightful observations point to the growing popularization of a more sophisticated conception of

${ }^{35}$ Ayesha Imam "Fighting the Political Abuse of Religion in Nigeria," WLUML 2004, 127.

${ }^{36}$ Baobab communiqué of the National Discussion on Women's Human Rights and Religion, available at http://www.wluml.org/english/newsfulltxt.shtml? cmd $\% 5 \mathrm{~B} 157 \% 5 \mathrm{D}=\mathrm{x}-157-546798$. Accessed on March 13, 2007. 
Gender Issues in Application of Islamic Law in Nigeria

Islamic law that is also more fully aware of its richness and flexibility than the narrower and less informed conceptions often paraded by the so-called shari'a proponents.

\section{E. Women's Access to Justice in Shari' ${ }^{6}$ Courts}

Heinrich Boll Foundation (HBF), another non-governmental organization actively engaged with the issues arising from recent developments in the application of Islamic law in Nigeria, seek ways to refocus public discourses on shari $a$ by de-escalating tensions and redirecting debates away from divisive issues and exclusive attention on criminal law only. ${ }^{37}$ Boll Foundation supports the "Shari" $a$ Information and Documentation Project" (SIDOP), based in Kano for "collecting and disseminating Sharia-related information under the aegis of experienced social scientists," and also providing "a focal point for debates about the wider societal impacts of the Sharia in Northern Nigeria." 38 The objectives of SIDOP includes: provision and distribution of "empirical, truthful and balanced information about the Sharia, its implementation, and the human rights situation in Northern Nigeria," de-escalation of "politicized sharia debate in Nigeria," and "to place human rights concerns - rather than identity politics and power tussles-back into the focus of public attention, as societies draw upon religious and traditional foundations to define their future." 39

In bringing supporters and critics of shari" a implementation "into dialogue with each other," Boll Foundations seeks to highlight what it thinks are the issues that really matter: "How can the introduction of shari' $a$ improve social conditions and justice? How can access to justice-especially for women and disadvantaged groups-be improved? How can we be sure that internationally accepted human rights standards are adhered to in the administration of shari "a justice?" This view is expressed in publication of papers and proceedings of "constructive dialogue about shar" $a$ in Nigeria" via conferences and

\footnotetext{
${ }^{37}$ http://www.boellnigeria.org/index.html, Accessed on May 20, 2007

${ }^{38} \mathrm{http}: / /$ www.boellnigeria.org/sidop.html, Accessed on May 28, 2007

${ }^{39}$ Ibid.
} 
seminars, the participants of which have included "experts of public and Islamic law, judges at High and Shari'a courts, and members of Nigerian and international human and women's rights groups." ${ }^{40}$ In these respects, the Boll Foundation finds common ground with some Muslims who have faulted the exclusive focus on reinstating the budúd punishments, without first seeking to establish an Islamic socio-political order, which can then be defended and protected by the stringent rules of Islamic law.

In February 2003, the Boll Foundation supported a conference on the theme of "women's access to justice under shari" $a$ in Northern Nigeria." WACOL (Women's Aid Collective) and WARD (Women Advocates Research and Documentation) are two women's rights NGOs that collaborated with the Department of Public Law of Ahmadu Bello University, Zaria, to organize the conference in Abuja. Against the background of an earlier strategic conference on Islamic Legal System and Women's Rights held in October 2002, this conference assessed and evaluated the implementation of shari' $a$ penal laws and justice system in Northern Nigeria, and its impact on women's human rights with the aim of determining issues, challenges and prospects in the protection of women's rights and guaranteeing access to justice under the shari" $a$. The objectives of the conference were "to make concrete suggestions and outline strategies on how to promote, protect and ensure women's rights under shari'a justice system; to strengthen networking for social and legislative advocacy for the promotion of women's rights in Islamic societies; and to improve women's access to justice through exchange of information." The participants at the conference-Muslim women groups, NGOs, Islamic jurists, judges, legal practitioners, and other intellectuals from Nigeria and abroad - made important observations regarding the potentials of protecting women's rights within the framework of Islamic law. In

\footnotetext{
${ }^{40}$ For example, see: Sheik U.D. Keffi "Improving the Quality of Life of Muslims through the Implementation of the Socio-economic Aspects of the Sharia in Nigeria," in J. Ngozi Ezeilo, Muhammad T. Ladan and Abiola A. Akiyode (eds.), Sharia Implementation in Nigeria: Issues and Challenges on Women's Rights and Access to Justice, (Abuja and Lagos: Women's Aid Collective and Women Advocates Research and Documentation Center, 2003), pp. 207-27.
} 
Gender Issues in Application of Islamic Law in Nigeria

this regard, the following remarks are particularly revealing:

"Shari' legal system recognizes and safeguards women's rights and access to justice as human beings ... Ignorance about Islamic law by women is the biggest threat to their rights and access to justice under the shari' $a$.... Education and enlightenment of the populace and those that implement shari' $a$ is important for a proper implementation of Islamic legal system ... Under Islamic legal system, there is no deliberate policy of bias against women. However, with regard to protecting rights and securing access to justice for women, it is necessary to prevent biases borne out of cultural, personal, or selfish reasons or even ignorance.... ${ }^{41}$

Following logically from their observations, the participants recommended that there should be "Improvement of women education and enlightenment about their rights as enshrined in shar ' $a, \ldots$ [via] establishing effective mechanisms for communicating women's interests and concerns, establishing institutions that will further enable women to access justice, such as legal aid services, and access to counsel without any distinctions." Furthermore, the participants also recommended:

"Shari' $a$ implementing states should intensify efforts in continuous training of Alkalis or judges on matters of shari' $a$, especially on procedure and evidence, in institutions of higher learning, for effective performance of their duties, including adequate funding.... Shari $a$ implementing states should take positive steps toward implementing the socio-economic components of shari" $a$. The Conference specifically recommends the establishment of the powerful Islamic "Mazalim" institution to tackle complaints against official misdeeds, including corruption and official breach of trust. ... In view of daily challenges, Nigerian Muslim jurists should embark on improvement of implementation of shari" a through the process of "ijtihad" (independent reasoning). ${ }^{42}$

41 “'Three-Day Conference on Women's Rights and Access to Justice under Shari'a in Northern Nigeria," Organized by Women's Aid Collective (WACOL) and Women Advocates Research and Documentation Center (WARDC) in collaboration with the Department of Public Law, Ahmadu Bello University (ABU), Zaria, with support from the Heinrich Boll Foundation at Rockview Hotel , Abuja on February 25-28, 2003, p. 1.

${ }^{42}$ Ibid., p. 2. 
With women's rights organizations actively promoting and advocating these views, it has become impossible to maintain a monolithic view of Islamic law in the public discourses in Nigeria. One positive consequence of this healthy development can be seen in translating these calls for promoting and defending women's human rights into specific arguments in court where particular individual women were charged with illicit sex, punishable by stoning to death upon conviction. Let us explore this point by analyzing the judgments in the two internationally celebrated cases.

\section{F. Shari'a Courts Judgments}

In the two cases of Safiyya Husaini (2002) and Amina Lawal (2003), different Shari'a Courts of Appeal from Katsina State and the Sokoto State set aside the judgments of lower Shari' $a$ Courts that have earlier convicted the two women of the offence of qina, and sentenced them to death by stoning, as stipulated in the newly enacted $\operatorname{shari}^{-} a$ codes. Careful analysis of these judgments reveals several important points, three of which deserve more detailed attention here, namely: the complexities of applying Islamic law in the contemporary nationstate of Nigeria; the link between the judgments delivered and the contentious politics of application of Islamic law, including the critical discourses generated by women's rights organizations in Nigeria and in many locations around the globe; and the doctrines of Islamic law that won in court.

The most notable aspects of the complexities of applying Islamic law in the context of contemporary nation-state of Nigeria is the legal pluralism that involves three different legal orders, namely: Islamic law, indigenous African laws of different tribes and ethnic groups, and the Nigeria's public law derived largely from British Common Law inherited from colonial period. These legal orders have increasingly become linked, particularly through the institutional imperatives of judicial administration, including organization of courts according to modern bureaucratic standards, recording of court proceedings in the form case-law reports, and most importantly, the doctrine of supremacy of Nigeria's constitution over all other laws. Awwalu Yadudu argues convincingly that the imposition of British common law traditions has 
Gender Issues in Application of Islamic Law in Nigeria

transformed the form and substance of Islamic law as applied in Nigerian courts. ${ }^{43}$ Aspects of this transformation are quite clear in the two judgments of the Shari' $a$ Courts of Appeal from Sokoto and Katsina States. The judges insist on upholding the supremacy of the 1999 constitution, which prohibits retroactive application of any criminal law, and also requires that crimes and their punishments must be defined by a written law before anyone could be convicted of such crimes. This constitutional norm means that zin $\bar{a}$ was not an offence before the Sharia Penal Codes of Sokoto and Katsina States were duly passed into law c. 2000-2002 by the respective legislative and executive authorities of the two states. The fact that budüd punishments have been part of Islamic law for centuries does not matter in light of the constitutional prohibition of retroactive legislations. One of the grounds of appeal upheld by the Qadis in the Amina Lawal case was the failure of the lower Shar 'a Courts to observe the requirements for the proper constitution of the court as stipulated in the recent legislation.

But while the learned Qadis of the Shari'a Courts of Appeal scrupulously adhered to statutory law, they were equally scrupulousor even more so-in insisting that the lower Shari 'a Courts were bound by all the elaborate stipulations of the classical manuals of Islamic law for conviction of zinā, including four irreproachable eye-witnesses to the actual sexual intercourse which they are certain was not lawful, as well as providing the accused with full and comprehensive explanation of the legal meaning of zina as technically defined in Islamic law, i.e. sexual intercourse that lacks any semblance of legality. The failure of the lower Shari'a Courts in these two respects was one of the reasons for setting aside their judgments and allowing the appeal to succeed. ${ }^{44}$ The insistence that lower Shari ${ }^{7} a$ Courts were bound by

${ }^{43}$ Awwalu H. Yadudu, "Colonialism and the Transformation of the Substance and Form of Islamic Law in Northern Nigeria," Journal of Law and Religion, 9 (1991), pp. $12-47$.

${ }^{44}$ See: The Law Reporting Committee, “Amina Lawal V. The State, Shari'a Court of Appeal Katsina," in Law Report of Nigeria 2003, (Zaria: Ahmadu Bello University Press, 2004), pp. 495 ff. Cf. ruling in "Safiyya Husaini v. Attorney General of Sokoto State," reported in Women's Aid Collective (WACOL) Safiyyatu's Case, (2003), pp. 20 ff. 
all the requirements for conviction arising from statutory Shari' $a$ Penal Codes passed by Sokoto and Katsina States, the upholding the supremacy of the 1999 constitution of the Federal Republic of Nigeria, as well as the adherence to medieval doctrines of Islamic law are clear pointers to the virtual convergence of Islamic law and the public law of the modern nation-state of Nigeria. It seems certain that one could not win a case in the Shari' $a$ Courts without adhering to certain aspects of the two different but converging legal orders.

It obvious that pressures from different political constituencies may have been exerted on the Shari' $a$ Courts of Appeal that discharged and acquitted Safiyya Husaini and Amina Lawal. As earlier discussed, many state governors were virtually stampeded into implementing shari' $^{-} a$ in the states through tremendous political pressure that could not have escaped the attention of the learned Appeal Qadis. Political pressure against application of $\operatorname{shari}^{-}$' , particularly the ḅudúd punishments, came from 1) the Federal Government of Nigeria, 2) the local human rights and women rights non-governmental organizations, and their international partners, and 3) governments of some Western countries, whose ambassadors in Nigeria made public statement of their opposition, including formal condemnation of carrying out of the budüd amputation and lashing in Zamfara State. Although different from each other, these three sources of political pressure against application of Islamic law were all connected in basing their oppositions on human rights doctrines whether in the form enshrined in the 1999 constitution of the Nigeria, or in the international treaties and covenants ratified by Nigeria and therefore making the country liable in international law, or in the public diplomacy of Western countries. The strategies of exerting political pressure against shari' $a$ application also varied. The Federal Government of Nigeria preferred arm-twisting of governors of shari' $a$ states behind-the-scene, while the local human rights and women's right non-governmental organizations assembled a team of lawyers and experts in Islamic law to defend the accused women in the Shari'a courts, invoking both Islamic law and Nigeria's public law. The defense team utilized the opposition from Nigerian Muslim liberals who publicly faulted several aspects of the judgments delivered by the lower Shari'a Courts in the Safiyya Husaini and Amina 
Gender Issues in Application of Islamic Law in Nigeria

Lawal cases; they were also very vocal in pointing the opportunism in the politics of applying the shari' $a$ and fact that the Shari' $a$ Penal Codes were heavily stacked against women and poor Muslims while allowing influential Muslim elites to escape prosecution of corruption and the stern punishment of b̧udüd.

An interesting aspect of the politics that brought pressure against application of budüd can be seen in the problem that developed when local women's rights resorted to mobilizing their international partners who waged an international campaign for petition against application of hudūd in Nigeria. When the international campaign began to snowball into Islamophobia, it became a counter-productive liability that the local non-governmental organizations had to call for ending the international campaign. ${ }^{45}$ In addition to public protestations by Western embassies in Nigeria, there was also a formal resolution from the European Union Parliament against the budüd sentences. ${ }^{46}$ As if all these outcries and denunciations were not enough, the international media sensationalism that invaded the relative anonymity of remote towns and rural communities in northern Nigeria must have added to the already tremendous pressure on the qadis of the Shar ' $a$ Courts of Appeal to find all possible ways to discharge and acquit the two hapless women in the eye of the storm, thereby de-escalating the tension that has been building both locally and internationally and at the same time averting the unwanted scrutiny from hostile quarters.

The unenviable task of the Appeal Qadis was made somewhat easier by a combination of factors, most notably the complexities of applying Islamic law in the modern nation-state of Nigeria as discussed already, and the rich flexibility of the doctrines of classical Islamic law. Any failure to meet strict evidentiary requirements for conviction of zina can easily lead to discharge of the accused. Furthermore, even if all the elaborate requirements were present, they accused could still avoid conviction by raising shubha, i.e. doubt on any aspect of the

${ }^{45}$ BAOBAB, "Implementation of the Sharia in Nigeria: The Journey So far," pp. 30-34

${ }^{46}$ European Union/Nigeria: Resolution on human rights situation in Nigeria; http://www.wluml.org/english/newsfulltxt.shtml? $\mathrm{cmd} \% 5 \mathrm{~B} 157 \% 5 \mathrm{D}=\mathrm{x}-157-3334$ Accessed on May 28, 2007. 
incriminating evidence presented in court. In Islamic law, it is acceptable for an accused to withdraw confession of guilt made in earlier stage. When Amina Lawal withdrew her previous confession of zina- - one of the two evidentiary bases of her conviction - she introduced shubha into the evidence against her, and thereby creating a basis for discharge and acquittal. The arguments for discharge became even strong when another shubha was introduced concerning her pregnancy outside of marriage- the second evidence for her conviction in the lower Sharia courts. In Islamic law the concept of dormant pregnancy means that any child born within less than five years after divorce legally belongs to the previous marriage. The fact that Amina Lawal's daughter was born only two years after her divorce means that the baby could legally belong to her previous husband. Thus with doubt hanging on the two evidentiary bases of her conviction, enough shubha has been created for the Qadis of the Shari'a Court of Appeal to avert the punishment of hadd for zina since according to a well-known tradition of the Prophet Muhammad, budüd punishment should be avoided even if by raising shubha. ${ }^{47}$

A number of procedural errors committed by the lower Shari' $a$ Courts also worked to the advantage of the accused. First, the doctrine of $i$ zar requires that the qadi should give the accused an opportunity to say anything that could help to avert conviction, but this was not properly observed by the judges of the lower Shari' $a$ Courts. According to the judges of the Shari'a Court of Appeal, it was not acceptable in Islamic law for police, or anyone for that matter, to start inquiry into the conduct of an individual in order to collect evidence for indictment; the judges held this to be a violation of Islamic legal protection of the privacy of the individual. ${ }^{48}$

\section{G. Conclusion}

By critical engagement with the classical manuals of Islamic law, women rights activists have discovered the centrality of human agency in constructing Islamic law in many different ways, including limiting

47 “Amina Lawal v The State," p.503-505.

48 “Safiyya Husaini v. Attorney General of Sokoto State," p. 30. 
Gender Issues in Application of Islamic Law in Nigeria

what the Qur'an allows. Working mainly within the narrow confines of figh, women have now acquired the valuable knowledge of the incredible variety and diversity in Islamic Law; they have also stumbled upon other aspects of classical intellectual traditions of Islam that arguably offer even more compelling evidence of both human agency and diversity within Islamic thought in general. These include doctrine of circumstances of revelation from Ulum al-Qur'an; criticism of chain of narrators and text of hadith from Ulum al-Hadith; and sources of Islamic law being not confined to the Qur'an and Prophetic Sunnah, but also more clearly human sources such as the ijtihäd of the individual jurists and consensus of the scholars. To specialists of Islamic Studies, these ideas are well known, but for Muslim without advanced knowledge of Islam, these ideas are eye-openers to the rich flexibility of classical Islam, which is quite different from the rigid understandings of Islam being advocated by contemporary extremists and militants.

In Morocco and Nigeria and many other Muslim counties women's rights are being debated, contested and defended in contemporary Islamic discourses by actively engaging with the classical heritage of Islamic thought rather than rejecting it, or simply ignoring it. The emerging field of Islamic Feminism or Gender Jihad is perhaps the most likely beneficiary of the increasing awareness of the richness of classical Islamic thought; but that richness can also enhance all sides in the contemporary debates on wide range of issues concerning Muslims as ordinary citizens of a modern state. In all these political engagements and intellectual encounters, classics of Islamic thought offer vast discursive resources to advocate and defend the legitimacy of not only the fundamentalist or extremist positions, but also tolerant and accommodating positions as well. 
Muhammad S. Umar

\section{BIBLIOGRAPHY}

Aliyu, Ibrahim A., "Shari'a Implementation So Far: Problems and Prospects," Journal of Islamic and Comparative Law, vol. 23, 2002.

An-Na'im, Abdullah A., Toward an Islamic Reformation, Syracuse, NY: Syracuse University Press, 1990.

Arkoun, Mohammed, Rethinking Islam, trans. and ed. by Robert D. Lee, Boulder, CO: Westview Press, 1994.

----, The Unthought in Contemporary Islamic Thought, London: Saqi, 2002.

Center for the Study of Islam and Democracy, The Implementation of Shari'a in a Democracy: The Nigerian Experience, Washington, DC 2006.

El Fadl, Khaled Abou, Speaking in God's Name, Oxford: Oneworld Publications, 2001.

Farid, Esack, Qur'an, Liberation and Pluralism, Rockford, MA: Oneworld Publications, 1997.

Human Rights Watch, "Political Sharia"? Human Rights and Islamic Law in Northern Nigeria," Human Rights Watch, vol. 16, no 9(A), September 2004.

Ibrahim, Jibrin, "Political Transition, Ethnoregionalism, and the "Power Shift' Debate in Nigeria," Issue: A Journal of Opinion, vol. 27:1, 1999 .

Imam, Ayesha, "Fighting the Political (Ab)Use of Religion in Nigeria: BOABAB for Women's Human Rights, Allies and Others," in Warning Signs of Fundamentalisms, edited by A. Imam, J. Morgan \& N. Yuval-Davis, published by Women Living under Muslim Law, 2004.

Imam, Ayesha M., Mufuliat Fijabi, and Hurera Akilu-Atta, Women's Rights in Muslim Laws: A Resources Document, Lagos: Baobab for Women's Human Rights, 2005.

Jega, A. ed., Identity Transformation and Identity Politics under Structural Adjustment in Nigeria, Uppsala: Nordic Africa Institute, May 2000.

Kalu, Ogbu U. ,"Safiyya and Adamah: Punishing Adultery with Sharia Stones in the Twenty-First Century Nigeria," African Affairs, 2003. 
Gender Issues in Application of Islamic Law in Nigeria

Keffi, Sheik U.D. "Improving the Quality of Life of Muslims through the Implementation of the Socio-economic Aspects of the Sharia in Nigeria," in J. Ngozi Ezeilo, Muhammad T. Ladan and Abiola A. Akiyode (eds.), Sharia Implementation in Nigeria: Issues and Challenges on Women's Rights and Access to Justice, Abuja and Lagos: Women's Aid Collective and Women Advocates Research and Documentation Center, 2003.

Kurzman, Charles, ed., Modernist Islam 1840-1940, New York: Oxford University Press, 2002.

Law Reporting Committee "Amina Lawal V. The State, Shari'a Court of Appeal Katsina," in Law Report of Northern Nigeria 2003, Zaria: Ahmadu Bello University Press, 2004.

Mernissi, Fatima, The Veil and the Male Elite: A Feminist Interpretation of Women's Rights in Islam, translated by Mary Jo Lakeland, Reading, Massachusetts: Addison-Wesley Publishing Co, 1991.

Moussalli, A.S., Islamic Quest for Democracy, Pluralism, and Human Rights, Gainesville, FL: U.P. of Florida, 2001.

Naniya, Tijjani M., "History of the Sharia in Some States of Northern Nigeria to circa 2000," Journal of Islamic Studies, vol. 13, no 1, 2002.

----, "Transformation of the Administration of Justice in Kano Emirates, 1903-1966," Ph.D. Dissertation, Bayero University, Kano, Nigeria, 1990.

Nmehielle, Vincent O., "Sharia Law in the Northern States of Nigeria: To Implement or Not to Implement, the Constitutionality is the Question," Human Rights Quarterly, vol. 24, 2004.

Osaghae, Eghosa E., Crippled Giant: Nigeria Since Independence, Bloomington: Indiana University Press, 1998.

Ostien, Philip, Jamila M. Nasir, and Franz Kogelman, (eds.) Comparative Perspectives on Shariah in Nigeria, Ibadan: Spectrum Books, 2005.

Ostien, P. "Islamic Criminal Law: What it means in Zamfara and Niger States," Journal of Public and Private Law, vol. 4, no 4, 2000.

Oyediran, O., L. Diamond, and A. Kirk-Greene, eds. Transition without End: Nigerian Politics and Civil Society under Babangida, Boulder, CO Lynne Rienner Publishers, 1997. 
Muhammad S. Umar

Peters, Ruud, The Reintroduction of Islamic Criminal Law in Northern Nigeria, A Study Conducted on Behalf of the European Commission, Lagos, 2001.

Sachedina, A., The Islamic Roots of Democratic Pluralism, New York: Oxford University Press, 2001.

Sanusi, Sanusi L. "Fundamentalist Groups and the Nigerian Legal System: Some Reflections," in Warning Signs of Fundamentalism, edited by A. Imam, J. Morgan \& N. Yuval-Davis, published by Women Living under Muslim Law, 2004.

Shahrur, M., Dirasāt al-Islämiyya al-Müàsira fi al-Dawla wa'-Mujtama', Damascus: Al-Ahli, 1994.

Smith, Daniel J. A Culture of Corruption: Everyday Deception and Popular Discontent in Nigeria, Princeton, NJ: Princeton University Press, 2006.

Soroush, Abdolkarim, Reason, Freedom, and Democracy in Islam: Essential writings of Abdolkarim Soroush, translated, edited, and with a critical introduction by Mahmoud Sadri and Ahmad Sadri, New York, N.Y.: Oxford University Press, 2000.

Umar, Muhammad S., Islam and Colonialism: Intellectual Responses of Muslims of Northern Nigeria to British Colonialism, Leiden: Brill, 2006.

Usman, Y. B. "Violent Ethnic Conflicts in Nigeria: Beyond Myths and Mystifications," Analysis, vol. 2 No 2, February 2003.

Wadud, Amina, Qur'an and Woman, New York: Oxford University Press, 1999.

Women's Aid Collective (WACOL) Safiyyatu's Case, Enugu, 2003.

Yadudu, Awwalu H. "Colonialism and the Transformation of the Substance and Form of Islamic Law in Northern Nigeria," Journal of Law and Religion, 9, 1991.

Young, Crawford. "The Impossible Necessity of Nigeria: A Struggle for Nationhood" Foreign Affairs, November/December 1996, http:/ /www.foreignaffairs.org/1996/6.html. 